Agrovoc descriptors: insecticides, corythucha, rosemary, rosmarinus officinalis, platanus, essential oils, pest control, efficiency, mortality, larvae, laboratory experimentation

Agris category code: $\mathrm{H} 10$

\title{
Insecticidal activity of four different substances against larvae and adults of sycamore lace bug (Corythucha ciliata [Say], Heteroptera, Tingidae)
}

\author{
Helena ROJHT ${ }^{1}$, Anja MEŠKO² ${ }^{2}$, Matej VIDRIH ${ }^{3}$, Stanislav TRDAN ${ }^{4}$
}

Received January 05, 2009, accepted January 6, 2009.

Delo je prispelo 5. januarja 2009, sprejeto 6. januarja 2009.

\begin{abstract}
In a paper the results of insecticidal activity of two known insecticides (deltamethrin and imidacloprid), thujone and essential oil of rosemary against the larvae and adults of sycamore lace bug (Corythucha ciliata) are presented. The experiment was conducted in a laboratory, under room conditions. We tested the activity of each product in three different concentrations. The most desirable insecticidal activity had deltamethrin, which caused almost $100 \%$ mortality of both developmental stages of the pest at all three concentrations. Succeeding products were imidacloprid, which caused $89.6 \%$ larval mortality at recommended concentration, and essential oil of rosemary, which caused $81.7 \%$ adult mortality at $1 \%$ concentration. Larvae of sycamore lace bug were significantly more susceptible to tested products than adults. Significantly the lowest mortality was determined one day after treatment $(41.7 \%)$, while the highest mortality was stated three days after treatment $(71.3 \%)$. For future reduction of the damage caused by the studied pest on plane trees, we recommend the application of thujone and essential oil of rosemary, which appeared to be environmentally more acceptable substances. In our study both agents showed a middle satisfying activity in controlling larvae and adults, but they have also obvious repellent activity, which leads to their better efficacy in the open.
\end{abstract}

Key words: Corythucha ciliata, sycamore lace bug, rosemary, thujone, imidacloprid, deltamethrin, efficacy, mortality, larvae, adults, laboratory testing

\author{
INSEKTICIDNO DELOVANJE ŠTIRIH SNOVI NA \\ LIČINKE IN ODRASLE OSEBKE PLATANOVE \\ ČIPKARKE (Corythucha ciliata [Say], Heteroptera, \\ Tingidae)
}

\section{IZVLEČEK}

$\mathrm{V}$ prispevku so predstavljeni rezultati insekticidnega delovanja dveh znanih insekticidov (deltametrin in imidakloprid), tujona in eteričnega olja rožmarina na ličinke in odrasle osebke platanove čipkarke (Corythucha ciliata). Poskus je bil opravljen $\mathrm{v}$ laboratoriju, $\mathrm{v}$ sobnih razmerah. Učinkovitost vsakega od pripravkov smo ugotavljali pri treh različnih koncentracijah. Najboljše insekticidno delovanje je imel deltametrin, ki je pri vseh koncentracijah povzročil skoraj 100 $\%$ smrtnost obeh razvojnih stadijev škodljivca. Sledi mu imidakloprid, ki je pri priporočeni koncentraciji povzročil 89,6 $\%$ smrtnost ličink in eterično olje rožmarina, ki je pri $1 \%$ koncentraciji povzročilo $81,7 \%$ smrtnost odraslih osebkov. Ličinke platanove čipkarke so bile signifikantno bolj občutljive na preizkušane pripravke kot odrasli osebki. Signifikantno najmanjšo smrtnost smo ugotovili prvi dan po tretiranju $(41,7 \%)$, največjo pa tretji dan po tretiranju $(71,3$ $\%)$ Z Za prihodnje zmanjševanje škodljivosti preučevane žuželke na platanah pa priporočamo uporabo tujona in eteričnega olja rožmarina, ki sta okoljsko sprejemljivejši snovi. Obe sta $v$ našem poskusu pokazali srednje zadovoljivo delovanje na ličinke in odrasle osebke, a imata tudi dokazano repelentno delovanje, s čimer lahko na prostem pričakujemo njuno boljšo učinkovitost.

Ključne besede: Corythucha ciliata, platanova čipkarka, rožmarin, tujon, imidakloprid, deltametrin, učinkovitost, smrtnost, ličinke, odrasli osebki, laboratorijsko preizkušanje

\footnotetext{
1 Chair of Phytomedicine, Agricultural Engineering, Crop Production, Grassland and Pasture Management, Jamnikarjeva 101, SI1111 Ljubljana, e-mail: helena.rojht@bf.uni-lj.si

2 ibid.

3 ibid.

4 ibid.
} 


\section{INTRODUCTION}

The native land of sycamore lace bug (Corythucha ciliata [Say], Heteroptera, Tingidae) is North America. This insect species was the most probably introduced into Europe over the port Genova in Italy (Öszi et al., 2005) and its appearance on plane trees in Old continent is stated since 1964 (Maceljski, 1985). In Slovenia, this species was for the first time recorded in 1975 (Gogala, $1981 / 82$ ). Nowadays, it is generally spread on plane trees all over the country. The bug was the most damaging in the eighties of previous century, but todays the range of its noxiousness is somewhat smaller due to natural enemies (Milevoj, 2004).

Adult is less than $4 \mathrm{~mm}$ in lenght. The broadened areas around and behind the head and the wing covers are partially transparent and gauze- or lace-like in structure. The wings are usually partially transparent. The swarming starts at the end of April or in the beginning of May and in favourable conditions the females can stay active till December. Females lay eggs of first generation on leaves already one week after swarming started, eggs of the second generation are laid at the end of June or at the start of July, and eggs of the third generation are laid along with favourable weather conditions in August or September. They overwinter as adults under loose bark of plane trees, leaf litter and crevices, and tolerate extreme temperatures as low as $24{ }^{\circ} \mathrm{C}$ (Jurc, 2005).

The adults of sycamore lace bug feed on the undersides of leaves with sucking juice, causing dessication of tissue, first near the veins, and subsequently affecting the entire leaf, which may drop prematurely. They produce droplets of liquid frass, which dry out as black spots on the lower surface of the leaves. Beside black excrements also many dark larvae and their casts can be found on the undersides of the leaves (Jurc, 2005). In addition to damaging trees with sucking plant juice and as such weakening them, the sycamore lace bug has become a major nuisance in Europe, as plane tree is a very popular shade tree in parks. And if trees are bothersome with this pest also aesthetic look suffers (Maceljski, 1995). In Europe sycamore lace bug feeds on American plane tree (Platanus occidentalis L.), Hybrid plane tree (P. x hispanica Muenchh.) and in minor extent also on Oriental plane tree $(P$. orientalis L.) (Jurc, 2005). In late summer or in autumn the feeding damage of sycamore lace bug is the most apparent on the upper surface of the leaves, initially causing a white stippling that can eventually progress into chlorotic or bronzed foliage and premature loss of leaves. In cases of severe infestations, trees may be defoliated in late summer. The bug has several natural enemies, which can reduce its numerousness during the growing period. Control of sycamore lace bug in foreign countries is related first of all to treat the barks in autumn or in early spring with the aim to supress the overwintering adults (Halbert and Meeker, 2001).

Rosemary (Rosmarinus officinalis L.) is evergreen Mediterranean shrub from the mint family (Lamiaceae). It is used in culinary, medicine and cosmetic industry (Petauer, 1993). Essential oil of rosemary acts as a repellent to insects (Thorsell et al., 1970; Hori, 1998; Amer et al., 2001; JiSen and ErrLieh, 2005), toxically or contact insecticidal (Padin et al., 2000; Amer et al., 2001; Papachristos and Stamopoulos, 2002; Isman, 2008) and reduce oviposition and feeding (Dover, 1985). Some constituents, which are in rosemary essential oil, are in a number of commercial insecticides (Isman, 2008).

Thujone is a cyclic ketone and an active component of essential oils (Petauer, 1993). It can be found in many plant species, such as: absinthium (Artemisia absinthium L.), common wormwood (A. vulgaris L.), common sage (Salvia officinalis L.), clary sage ( $S$. sclarea L.), tansy (Tanacetum vulgare L.) and northern whitecedar (Thuja occidentalis L.) (Albert-Puleo, 1978). The name to this substance was given after the northern whitecedar from which it was extracted for the first time (Patočka and Plucarb, 2003). Thujone acts as a repellent agents to insects (Alfaro et al., 1981; Hwang et al.., 1985). SangKyun et al. (1997) confirmed high mortality of the western corn rootworm larvae due to acute poisoning with thujone. Beside previous charasteristic, thujone has also antibacterial properties (Nin et al., 1995).

The aim of our research was to study the activity of two synthetic insecticides (deltamethrin and imidacloprid), which application in other countries is advised when controling sycamore lace bug on plane trees (Kukedi and Palmai, 1992; Marchetti, 2003). At the same time we wanted to compare their efficacy with two environmentally acceptable products (rosemary and thujone). In case if the efficacy of natural products would be at least comparable to the efficacy of synthetic insecticides, we would have a good basis for the implementation of environmentally friendly products into strategy of controling sycamore lace bug. This step could contribute to protection of the environment in which we live. 


\section{EKOFIZIOLOŠKA VLOGA AM GLIV}

AM glive so zelo pomembne pri kroženju hranil in ogljika v naravi, čeprav zaradi kompleksnosti in omejenega poznavanja njihova vloga $\mathrm{v}$ tem kontekstu pogosto ni zadosti upoštevana. Pri arbuskularni mikorizi se običajno pojavlja mutualističen tip simbioze, odnos, kjer je glivni partner energetsko povsem odvisen od gostiteljskih rastlin (biotrof), saj je preskrba glive $\mathrm{z}$ ogljikovimi hidrati popolnoma vezana na gostitelje. V zameno za rastlinske asimilate AM glive preskrbujejo rastline $\mathrm{z}$ mineralnimi hranili. Fosfatni ioni $\mathrm{v}$ tleh pogosto tvorijo netopne spojine $\mathrm{z}$ večino kationov $\left(\mathrm{Al}^{3+}\right.$, $\left.\mathrm{Fe}^{3+}, \mathrm{Ca}^{2+}\right)$ in tako postanejo za rastlinske korenine težko dostopni. Ker je fosfor $\mathrm{v}$ tleh zelo slabo mobilen element, pogosto predstavlja omejujoč dejavnik rasti rastlin. V nasprotju s prepričanjem izpred nekaj let, je v zadnjem času vedno več dokazov, da lahko poleg preskrbe s fosforjem AM glive vplivajo tudi na preskrbo rastlin $\mathrm{z}$ drugimi hranili, $\mathrm{z}$ mikroelementi $(\mathrm{Cu}, \mathrm{Zn})$ ter kot kaže tudi $\mathrm{z}$ dušikom. $\mathrm{Z}$ uporabo stabilnih izotopov dušika in ogljika $\left({ }^{15} \mathrm{~N} /{ }^{13} \mathrm{C}\right)$ so ugotovili, da lahko kolonizacija z AM glivo Glomus hoi obenem vpliva na razgradnjo organske snovi $\mathrm{v}$ tleh ter poveča privzem dušika $\mathrm{v}$ rastlino iz organskega materiala (opad trav) (Hodge in sod., 2001), vendar pri teh procesih še ni poznana vloga drugih talnih mikroorganizmov pri razgradnji organskega materiala (Smith in Read, 2008). Podobno Govindarajulu in sod. (2005) poročajo o novo odkriti presnovni poti AM gliv, ki vključuje vgradnjo anorganskega dušika $\mathrm{v}$ aminokislino arginin znotraj zunajkoreninskega micelija in asimilacijo dušika $\mathrm{v}$ rastlino preko znotrajkoreninskega micelija ob razgradnji arginina. Izboljšana preskrba rastlin s hranili je najbolj izpostavljena vloga glive $\mathrm{v}$ mikorizi, poleg te pa ima simbioza rastlin $\mathrm{z}$ AM glivami še druge pozitivne učinke (Smith in Read, 2008) kot so izboljšana preskrba rastlin $\mathrm{z}$ vodo, varovanje pred patogeni in boleznimi, varovanje pred škodljivimi snovmi (npr. težke kovine), dokazana pa je tudi vloga zunajkoreninskega micelija in kot kaže tudi nekaterih produktov AM gliv (npr. glomalina) pri stabilizaciji strukturnih agregatov tal (Wright in Upadhyaya, 1998) ter $\mathrm{s}$ tem pozitiven vpliv na strukturo in rodovitnost tal.

\section{MATERIALS AND METHODS}

The experiment in which we studied insecticidal activity of two synthetic insecticides (deltamethrin and imidacloprid) and two plant substances (essential oil of rosemary and thujone) against the larvae and adults of sycamore lace bug was carried out in 2008 in Entomological Laboratory of the Chair of Phytomedicine, Agricultural Engeeniring, Crop Production, Grassland and Pasture Management (Dept. of Agronomy, Biotechnical Faculty) in Ljubljana. We used the following products: contact insecticide Decis 2.5 EC (manufacturer: Bayer CropScience SA, Lyon, France; active ingredient deltamethrin $25 \mathrm{~g} / \mathrm{l}$ ), systemic insecticide Confidor SL 200 (manufacturer: Bayer CropScience, Monheim, Germany; active ingredient imidacloprid $200 \mathrm{~g} / \mathrm{l}), \alpha+\beta$-thujone technical (manufacturer: Sigma-Aldrich, Buchs, Switzerland) and essential oil of rosemary (distributor: Ars Trade, Trzin, origin Tunisia). Larvae and adults of sycamore lace bug were collected from the leaves of Hybrid plane trees (Platanus $\mathrm{x}$ hispanica Muench.) in Ljubljana. From the same trees also undamaged leaves were collected. They were used later in the experiment in a Petri dishes.

We conducted the experiment at room conditions $\left(22 \pm 2{ }^{\circ} \mathrm{C}\right.$, natural sunlight). We applied products Decis $2.5 \mathrm{EC}$ and Confidor SL 200 at following concentrations: $50 \%$ (one half of recommended dose for sucking insects, stated in instructions for use), $100 \%$ (recommended dose for sucking insects, stated in instructions for use) and $200 \%$ (double recommended dose for sucking insects, stated in instructions for use). Recommended dose of insecticide Decis 2.5 EC is $0.04 \%$ for sucking insects and for Confidor 200 SL the same dose is $0.05 \%$. For thujone and essential oil of rosemary we applied concentrations, which showed in our preliminary experiments to be appropriate and so we set concentrations for thujone at $0.01 \%, 0.1 \%$ and $1 \%$ and for essential oil of rosemary at $0.1 \%, 0.5 \%$ and $1 \%$. We selected these concentrations on the basis of insecticidal activity ob both substances on other studied pests and their phytotoxicity. For better mixing of thujone and essential oil of rosemary with water we used sticky extending agent Nu-Film-17 (manufacturer: Lances Link SA, Geneva, Switzerland, active ingredient di-1-p-menthen $96 \%$ ).

We carried out the experiment in plastic Petri dishes, which were $14 \mathrm{~cm}$ in diameter. We put a filter paper (manufacturer: Tosama d.d., Vir, Slovenia) on the bottom of each Petri dish and above a leaf of Hybrid plane tree was laid. In treatment with Confidor SL 200 we first soaked leaves of plane tree in a solution with a appropriate concentration of insecticide, allowed leaves to dry up and only then we put 10 larvae or 10 adults of studied pest in individual Petri dish. In other treatments we laid first in each Petri dish 10 larvae or 10 adults and only then used hand sprayer and sprayed leaves according to concentrations. In control (untreated) Petri dishes we only soaked leaves in water. Each treatment in an experiment was repeated ten times.

We assessed larval and adult mortality of sycamore lace bug one, two and three days after exposure to the substances with counting dead specimen. The results were adjusted with Abbott's formula for corrected mortality (Abbott, 1925). We evaluated results of corrected mortality (analysis of variance, Duncan's multiple range test, $P \leq 0.05$ ) with Statgraphics Plus for Windows 4.0 software and for graph displays we used MS Office Excel 2003.

Acta agriculturae Slovenica, 93 - 1, maj 2009 


\section{RESULTS WITH DISCUSSION}

Pooled statistical analysis showed that larval and adult mortality were significantly influenced by day after treatment $(P<0.0001)$, substance $(P<0.0001)$ and their concentration $(P<0.0001)$. Significantly the highest mortality was caused by insecticide Decis 2.5 EC $(97.4$ $\pm 0.5 \%$ ), followed by $\alpha+\beta$-Thujone $(49.5 \pm 1.9 \%)$. Significantly the lowest mortality caused essential oil of rosemary $(40.4 \pm 2.1 \%)$ and insecticide Confidor SL $200(39.1 \pm 1.9 \%)$. We determined significantly the lowest mortality first day after treatment $(41.7 \pm 2.2 \%)$ and the highest mortality third day after treatment $(71.3$ $\pm 1.7 \%)$. Sycamore lace bug larvae were significantly more susceptible to tested substances $(62.4 \pm 1.4 \%$ mortality) than adults $(50.8 \pm 1.8 \%)$.

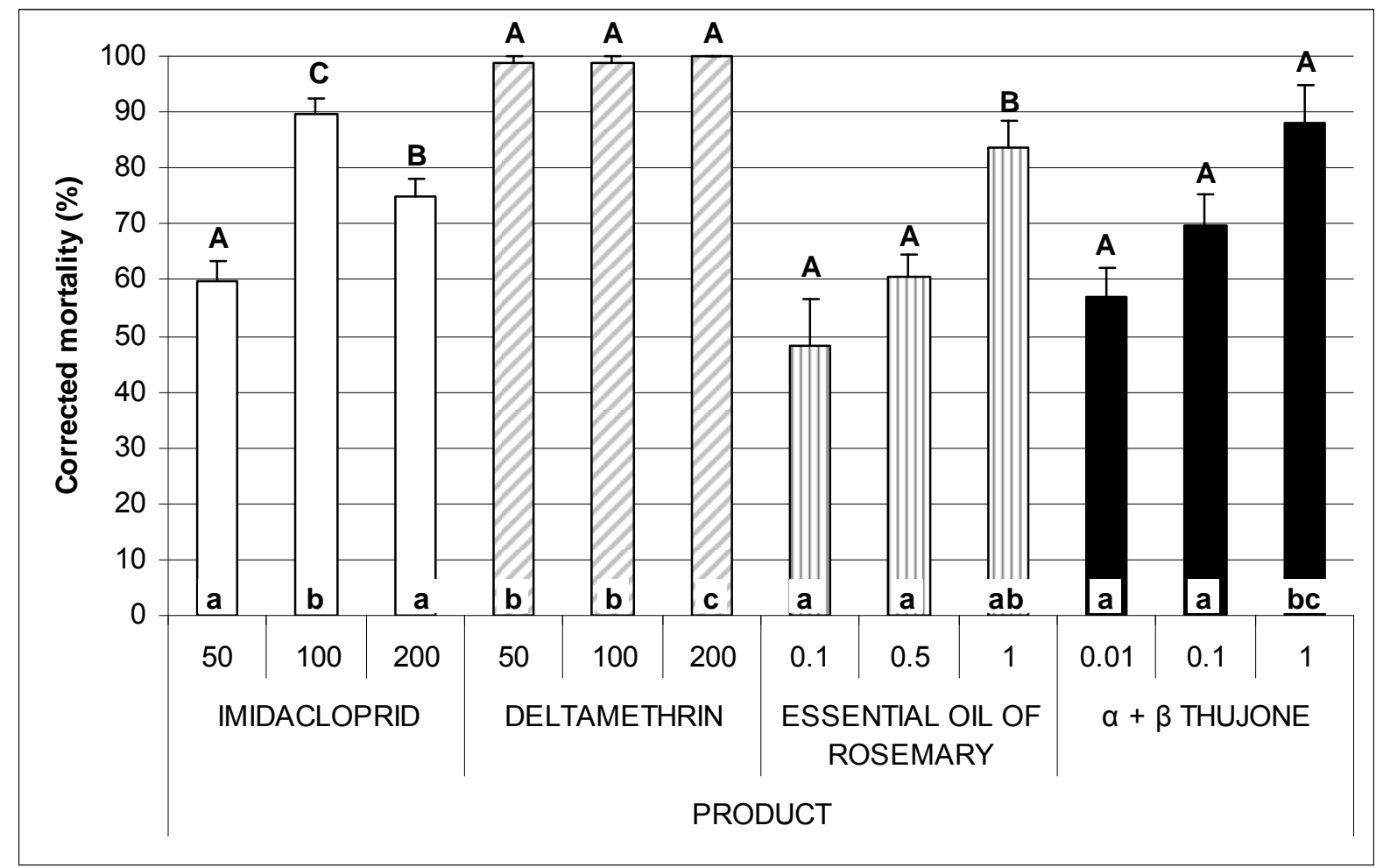

Figure 1: Percentage of larval mortality of sycamore lace bug (Corythucha ciliata [Say]) regarding the product and their concentrations three days after treatment. Different capital letters correspond to statistically significant differences between different concentrations within each substance and lower-case letters correspond to statistically significant differences between comparable concentrations of different substancess (Duncan's multiple range test, $P$ $\leq$ 0.05). Values 50, 100 and 200 denote to one-half, recommended and double recommended concentration of substances and values 0.01, 0.1, 0.5 and 1 denote to concentrations of the substances. All values are expressed as precentage.

For the time being there are no registered insecticides for controlling sycamore lace bug in Slovenia, although they cause damage on plane trees all over the country. In Hungary, they recommend spraying of tree trunks with deltamethrin in March as a control method (Kukedi in Palmai, 1992). Also in our experiment deltamethrin caused the highest mortality of larvae and adults of sycamore lace bug; already for a half lower concentration from that which is recommended for sucking insects, namely caused almost total mortality of exposed individuals $(98.8 \pm 1.2 \%$ mortality by larvae and $98.9 \pm 1.1 \%$ mortality by adults) (Figs. 1 and 2).

In North America more measures in controlling sycamore lace bug are known among which also an application of systemic insecticide, which is applied into the soil or injected into the bark, is known (Halbert and Meeker 2001). Systemic insecticide imidacloprid was also used in our experiment, however, it did not showed such an efficacy as contact insecticide deltamethrin. Highest mortality, which was caused by Confidor, was besides recommended concentration for 
sucking insect attained by larvae at $89.6 \pm 2.7 \%$ and by adults at $59.1 \pm 5.1 \%$. At double recommended concentration the mortality was surprisingly lower (larvae at $74.8 \pm 3.3 \%$ and adults at $49.4 \pm 4.6 \%$ ). We attribute this result to repellent activity of the product in such a high concentration to studied pest. Suchlike individuals fed less intensive or avoided to treated surface. For these two reasons their mortality was lower.
Essential oil of rosemary was generally observed as effective as systemic insecticide imidacloprid; satisfying enough at concentration of $1 \%$ it controlled larvae $(83.6 \pm 4.8 \%$ mortality) and adults $(81.7 \pm 5.5$ $\%$ mortality). We did not find statistically significant differences between thujone and essential oil in their efficacy at $1 \%$ concentration. Thujone controlled larvae and adults similar as rosemary, and former substance at $1 \%$ concentration caused $88.1 \pm 6.6 \%$ larval mortality and $76.2 \pm 4.8 \%$ adult mortality.

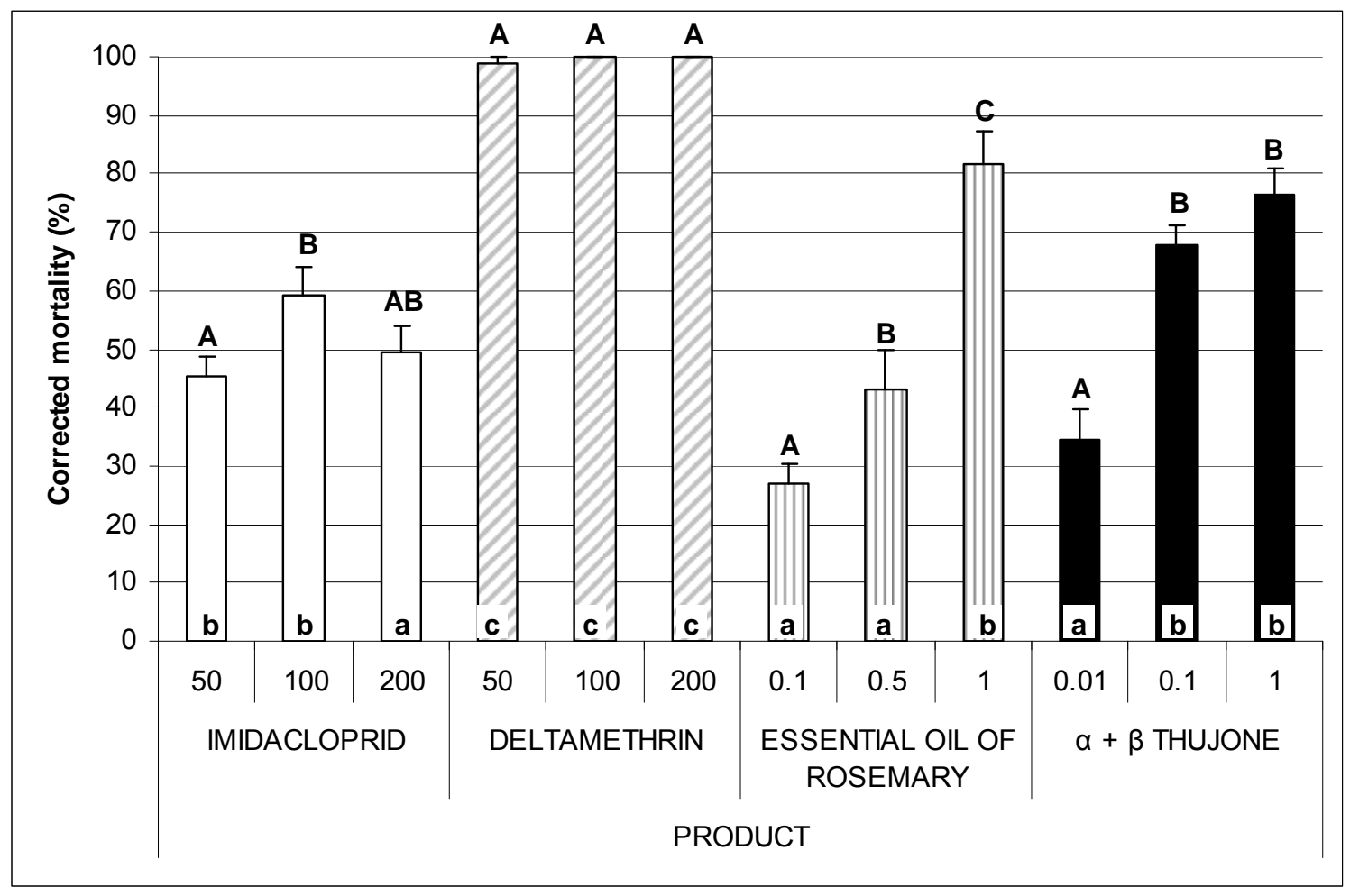

Figure 2: Percentage of adult mortality of sycamore lace bug (Corythucha ciliata [Say]) regarding the product and their concentrations three days after treatment. Different capital letters correspond to statistically significant differences between different concentrations within each substance and lower-case letters correspond to statistically significant differences between comparable concentrations of different substance (Duncan's multiple range test, $P \leq$ 0.05). Values 50, 100 and 200 denote to one-half, recommended and double recommended concentration of substances and values 0.01, 0.1, 0.5 and 1 denote to concentrations of the substances. All values are expressed as precentage.

For controlling sycamore lace bug in the near by future there should be used environmentally acceptable measures, yet spraying of tall trees such as plane trees are in urban area is less and less desired and also costly when taking into account the efficacy (Halbert and Meeker 2001).

Among environmentally acceptable approach belong also raking and destroying of defoliated leaves in autumn and peeling off senescened layer of bark in November (Kukedi and Palmai, 1992). Thujone and essential oil of rosemary, which have among others also repellent activity to insects (Hwang et al., 1985; Hori, 1998), could be applied on/under the bark of plane trees in autumn time usually before adults start to find the place to overwinter. In such a way mentioned substances, which showed in our experiment also middle satisfying activity in controlling larvae and adults of sycamore lace bug, could diverted them from places appropriate for overwintering and their number would diminished. At the same time the bark from previous years, which has beautiful and decorative appearance, could stay. 


\section{ACKNOWLEDGEMENT}

This work was supported by the Slovenian Research

Agency and the enterprise Unichem d.o.o. (Sinja gorica, Slovenia) within the program L4-1013.

\section{REFERENCES}

Abbott, W. S. 1925. A method of computing the effectiveness of an insecticide. J. Econ. Entomol. 18: 265-267.

Albert-Puleo, M. 1978. Mythobotany, pharmacology, and chemistry of thujone-containing plants and derivatives. Econ. Bot. 32: 65-74.

Alfaro, R. I., Pierce, H.D., Borden, J. H., Oehlschlager, A. C. 1981. Insect feeding and oviposition deterrents from western red cedar foliage. J. Chem. Ecol. 7: 39-48.

Amer, S. A. A., Refaat, A. M., Momen, F. M. 2001. Repellent and oviposition-deterring activity of rosemary and sweet marjoram on the spider mites Tetranychus urticae and Eutetranychus orientalis (Acari: Tetranychidae). Acta Phytopathol. Entomol. Hung. 36: 155-164.

Dover, J. W. 1985. The responses of some Lepidoptera to labiate herb and white clover extracts. Entomol. Exp. Appl. 39: 177-182.

Gogala, M. 1981/82. Platanina čipkarica, uvožena škodljivka platan. Proteus 44: 332-334.

Hori, M. 1998. Repellency of rosemary oil against Myzus persicae in a laboratory and in a screenhouse. J. Chem. Ecol. 24: 1425-1432.

Halbert, S. E., Meeker, J. R. 2001. Sycamore lace bug Corythucha ciliata. Featured Creature. Florida Department of Agriculture and Consumer Services, Divisions of Plant Industries and Forestry. (11. 11. 2008) $\mathrm{http}: / /$ creatures.ifas.ufl.edu/trees/sycamore_lace_bug.htm (september 2007)

Hwang, Y. S., Wu, K. H., Kumamoto, J., Axelrod, H., Mulla, M. S. 1985. Isolation and identification of mosquito repellents in Artemisia vulgaris. J. Chem. Ecol. 11: 1297-1306.

Isman, M. B., Wilson, J. A., Bradbury, R. 2008. Insecticidal activities of commercial rosemary oils (Rosmarinus officinalis) against larvae of Pseudaletia unipuncta and Trichoplusia $n i$ in relation to their chemical compositions. Pharm. Biol. 46: 82-87.

JiSen, H., ErrLieh, H. 2005. The repellent effect of several repellent plants on the mosquito and house fly. Formos. Entomol. 25: 221-230.
Jurc, M. 2005. Gozdna zoologija. Univerzitetni učbenik. Oddel. gozd. obnovljive gozd. vire, Bioteh. fak., Ljubl.: $348 \mathrm{pp}$.

Kukedi, E., Palmai, O. 1992. Studies on the sycamore tingid (Corythuca ciliata Say, Heteroptera, Tingidae) in Martonvasar. Növvéd. 28: 499-503.

Marchetti, L. 2003. Plant protection in ornamental and forest plants. Infor. Agrar. 59: 89.

Maceljski, M. 1986. Current status of Corythuca ciliata in Europe. Bull. OEPP/EPPO Bull. 16: 621-624.

Milevoj, L. 2004. The occurence of some pests and diseases on horse chestnut, plane tree and Indian bean tree in urban areas of Slovenia. Acta Agric. Slov. 83: 297-300.

Nin, S., Arfaioli, P., Bosetto, M. 1995. Quantitative determination of some essential oil components of selected Artemisia absinthium plants. J. Essent. Oil Res. 7: 271-277.

Őszi, B., Ladányi, M., Hufnagel, L. 2005. Population dynamics of the sycamore lace bug, Corythucha ciliata (Say) (Heteroptera: Tingidae) in Hungary. Appl. Ecol. Environ. Res. 4: 135-150.

Padin, S., Ringuelet, J. A., Bello, D., Cerimele, E. L., Re, M. S., Henning, C. P. 2000. Toxicology and repellent activity of essential oils on Sitophilus oryzae L. and Tribolium castaneum Herbst. J. Herbs, Spices \& Med. Plants 7: 67-73.

Papachristos, D. P., Stamopoulos, D. C. 2002. Repellent, toxic and reproduction inhibitoryeffects of essential oil vapours on Acanthoscelides obtectus (Say) (Coleoptera: Bruchidae). J. Stored Prod. Res. 38: 117-128.

Patočka, J., Plucarb, B. 2003. Pharmacology and toxicology of absinthe. J. Appl. Biomed.: 199-205

Petauer, T. 1993. Leksikon rastlinskih bogastev. Teh. založ. Slov., Ljubl.: 684 p.

Thorsell, W., Mikiver, A., Mikiver, M., Malm, E. 1970. Plant extracts as protectants against disease-causing insects. Entomol. Tidskr. 100: 138-141. 